\title{
Relationship of Geriatric Nutritional Risk Index (GNRI) with length of hospitalization and mortality rate in elderly patients
}

\author{
Retno Ambarukminingsih ${ }^{*}$, I Dewa Putu Pramantara², Neneng Ratnasari ${ }^{2}$ \\ ${ }^{1}$ Departement of Internal Medicine, Wates District Hospital, ${ }^{2}$ Departement of Internal \\ Medicine, Faculty of Medicine, Universitas Gadjah Mada/Dr. Sardjito Hospital Yogyakarta
}

\section{ABSTRACT}

The proportion of elderly population is growing faster than any other age group. Malnutrition is a widespread problem in elderly and has been recognized as the most common cause of mortality and morbidity. Mini Nutritional Assessment (MNA) is recommended to detect malnutrition risk among geriatrics. However, it is just appropriate for geriatric who stay at home. For hospitalization patients, Nutritional Risk Index (NRI) that using albumin and weight is recommended. However, the weight data is often not possible obtained in geriatrics. Therefore, Geriatric Nutritional Risk Index (GNRI) using ideal body weight is recommended. The aim of this study was to evaluate relationship of GNRI with length of hospitalization and mortality rate in geriatric patients. This was an observational study with a prospective cohort design conducted in Dr. Sardjito General Hospital, Yogyakarta from January to February 2012. Patients who met the inclusion and exclusion criteria were recruited. Laboratoty and clinical examinations as well as GNRI scoring were then performed. Patients were grouped into two groups i.e. patients with GNRI score $<82$ and $e^{\prime \prime}$ 82. The patients were then monitored during hospitalization until they were discharged due to die or recovered. The length of stay and patients died were then recorded. The results showed that the length of stay of patients with GNRI score $<82(14.32 \pm 8.20$ days) was significantly longer than those with GNRI score $\square 82(9.31 \pm 6.15$ days) $(p=0.006)$. Moreover, the mortality rate of patients with GNRI score $<82(42.1 \%)$ was significantly higher than those with GNRI score $\square 82(2.8 \%)(p=0.000)$. Kaplan-Meier survival analysis showed survival rate of patients with GNRI score < 82 rapidly decreased when compared with those with GNRI score $\square 82$. In conclusion, there is negative correlation between GNRI with length of hospitalization and mortality rate in elderly.

\section{ABSTRAK}

Proporsi populasi usia lanjut tumbuh lebih cepat dari kelompok usia lain. Malnutrisi menjadi masalah luas pada usia lanjut dan diketahui sebagai penyebab umum kesakitan dan kematian. Mini Nutritional Assessment (MNA) direkomendasikan untuk mendeteksi risiko malnutrisi diantara usia lanjut. Namun demikian, pengukuran ini hanya tepat untuk usia lanjut yang tinggal di rumah. Untuk pasien di rumah sakit, Nutritional Risk Index (NRI) yang menggunakan data albumin dan berat badan direkomendasikan. Akan tetapi data berat badan sering tidak bisa diperoleh pada usia lanjut. Sehingga, Geriatric Nutritional Risk Index (GNRI) menggunakan berat badan ideal direkomendasikan. Tujuan penelitian ini adalah mengkaji hubungan antara GNRI dengan lama tinggal dan kematian pasien usia lanjut. Penelitian ini merupakan penelitian observasional dengan rancangan kohort prospektif yang dilakukan di RSUP Dr. Sardjito, Yogyakarta pada Januari sampai Februari 2012. Pasien yang memenuhi kriteria inklusi dan eksklusi direkrut. Pemeriksaan laboratorium dan klinik dan perhitungan angka GNRI dilakukan. Pasien dikelompokkan menjadi dua kelompok yaitu kelompok pasien dengan angka GNRI $<82$ dan $\square 82$. Pasien kemudian dimonitor selama di rawat sampai keluar karena meninggal atau sembuh. Selanjutnya lama tinggal dan kematian pasien dicatat. Hasil penelitian menunjukkan lama tinggal pasien dengan angka

\footnotetext{
* corresponding author: rr_retnoambar@yahoo.co.id
} 
GNRI $<82(14,32 \pm 8,20$ hari) lebih lama dibandingkan dengan pasien dengan angka GNRI e" $82(9,31 \pm 6,15$ hari) ( $p=0,006)$. Selain itu, tingkat kematian pasien dengan angka GNRI $<82$ $(42,1 \%)$ lebih tinggi secara nyata dibandingkan pasien dengan angka GNRI $\square 82(2,8 \%)(p=$ 0.000). Hasil analisis survival dengan Kaplan-Meier menunjukkan survival rate pasien dengan GNRI < 82 menurun cepat dibandingkan pasien dengan angka GNRI $\square$ 82. Dapat disimpulkan, ada hubungan terbalikkan antara GNRI dengan lama tinggal di rumah sakit dan angkat kematian pada usia lanjut.

Keywords : Geriatric Nutritional Risk Index - length of hospitalization - mortality - elderly malnutrition

\section{INTRODUCTION}

The proportion of elderly population is growing faster than any other age group. It is estimated that the elderly population, person 65 years or older, will grow four time faster than the average of world population growth in 2050 . This demographic transition occurs due to the decrease mortality and women fertility rates. ${ }^{1,2}$

Malnutrition is a widespread problem in the elderly and has been recognized as the most common cause of secondary immunological dysfunction. ${ }^{3}$ Malnutrition has the potential to cause serious problems and is often underdiagnosed among the elderly. The importance of early detection and aggressive intervention is essential to overcome this problem. Correct diagnosis depends on the status of nutrition and the screening tools available. After malnutrition was diagnosed, we can determine intervention to the underlying problem. ${ }^{4}$

Some guidelines recommend the use of the Mini Nutritional Assessment (MNA) to detect risk of malnutrition among elderly subjects aged $>70$ years. The MNA assessment is based on a questionnaire and does not use a biological indicator. ${ }^{5}$ Because of the questionnaire's natural bias, MNA is more suitable for elderly who live at homes or nursing homes than during hospitalization. For adult patients who were hospitalized, it is recommended to use a combination of Body Mass Index (BMI, in kg/ m2) and weight loss or Nutritional Risk Index (NRI). Nutritional Risk Index combines two indicators of nutrition (albumin and weight loss), unfortunately it is often not possible to obtain the data of body weight in elderly patients. Therefore, the formula of Geriatric Nutritional Risk Index (GNRI) using ideal body weight (BW) should be prepared. Ideal BW is calculated according to the Lorentz formula that takes the patient's height and gender into account. Height is difficult to measure in patients who are hospitalized because they are often unable to stand. Therefore, it is estimated using the equation based on the high Chumlea knee (Knee height). ${ }^{6,7}$

There is a difference between the risk index related to nutritional status and indices of nutrition and malnutrition. Geriatric Nutritional Risk Index is not an index of malnutrition, but it is risk index that related to nutritional status. Therefore, GNRI score corelates to complications due to nutritional status. ${ }^{6}$ The GNRI has been introduced since 2005 as early screening in patients with malnutrition high risk. ${ }^{8}$ Therefore early treatment can be conducted and length of stay, cost, morbidity and mortality can be reduced. This study was conducted to evaluate the relationship of GNRI with length of hospitalization and mortality rate in elderly patients in Dr. Sardjito General Hospital, Yogyakarta 


\section{MATERIALS AND METHODS}

\section{Subjects}

This was an observational study with a prospective cohort design to evaluate the mortality rate and length of stay of elderly patients who admitted to the Internal Medicine Ward, Dr. Sardjito General Hospital, Yogyakarta and met the inclusion and exclusion criteria. The study was conducted from January to February 2012. The inclusion criteria were elderly patients (e" 60 years) admitted to the Internal Medicine Ward who were willing to participate in the study, whereas the exclusion criteria were the patients with severe liver disease, severe renal disease, coma patients, patients coming for chemotherapy, and patients who went home at their own or family request. The protocol of this study has approved by Medical and Health Research Ethics Committee, Faculty of Medicine, Universitas Gadjah Mada, Yogyakarta.

\section{Procedure of study}

Geriatric patients who admitted to the Internal Medicine Ward were selected. An explanation concerning background, objectives, benefit of the study was given. The patients who fulfilled the inclusion and exclusion citeria were given an informed consent to be signed. Laboratoty and clinical examinations consisting serum albumin and hemoglobin $(\mathrm{Hb})$ level, body weight (BW) and body height $(\mathrm{BH})$, Body Mass Index (BMI), knee height, upper arm circumference, depression status, and GNRI scoring were then performed. The patients were then monitored during hospitalization until they were discharged from the hospital due to died or recovered. The lenght of stay and patients died were recorded.

The measurement of serum albumin $(\mathrm{g} / \mathrm{dL})$ and $\mathrm{Hb}(\mathrm{g} / \mathrm{dL})$ levels were performed in Pathology Laboratory, Dr. Sardjito General
Hospital. Body weight $(\mathrm{kg})$ and $\mathrm{BH}(\mathrm{cm})$ were measured a portable stadiometer. For non ambulatory patients, estimation of their BW was performed by measurement of their upper arm circumference. For patients who could not be measured their BH, estimation of their $\mathrm{BH}$ was performed according to the Chumlea equation based on their knee height. The BMI of patients was measured by the formula of BW divided by $\mathrm{BH}$ and calculated as $\mathrm{kg} / \mathrm{m}^{2}$ according to WHO. ${ }^{9}$ For non ambulatory patients, BMI was calculated according to the Powell-Truck formula. Depression status of the patients was performed by an independent physician according to the Diagnostic and Statistical Manual IV - Text Revision (DSM IV-TR). Comorbidity Index was calculated based on patient's diagnosis. For each desease, a number of points were allocated according to Charlson Comorbidity Index and the sum of these points gived an overall score. The Comorbidity Index indicating risk relative to mortality was then categorized into two groups i.e. patients with Charlson score of $\leq 3$ and $>3$.

GNRI was determined by the following formula: $\mathrm{GNRI}=(1.489 \mathrm{x}$ albumin $\mathrm{g} / \mathrm{L})+(41.7$ $\mathrm{x}$ weight/ideal BW). ${ }^{6}$ Severe renal impairment was defined if creatinine clearance $<15 \mathrm{~mL} / \mathrm{h}$ according to the Cockcroft and Gault. Severe hepatic impairment was defined if clinical symptoms of liver impairment such as jaundice, hepatomegaly or ascites were observed. Patient was considered to have ascites if Child-Pugh scale was grade $\mathrm{C}$ or total score of $10-15 .^{10}$

\section{Statistical analysis}

Data were presented as mean \pm standard deviation (SD) or median (minimum-maximum) or percent depending on types of data. The relationship of GNRI and length of stay was analyzed using Pearson correlation for normally distributed data or Spearman correlation for abnormally distributed data. Multivariate analysis was performed to evaluate risk factors that influenced mortality and length of stay. 


\section{RESULTS}

Sixty elderly patients who met the inclusion and exclusion criteria involved in this study. All the patients underwent anthropometric and laboratory examination as well as GNRI measurement. The patients were then monitored their health status during hospitalized until they died or came back home from the hospital. During the monitoring, five patients could not follow the obseravtion and dropped out of the study, therefore only subjects completed this study.

The characteristics of patients are presented in TABLE 1 . Thirty (65\%) male and $19(34.5 \%)$ female subjects were recruited in this study with the mean age of $67.82 \pm 5.91$ years, Charlson Cormobidity Index of $3.36 \pm 2.35$ and length of stay of $11.04 \pm 7.27$ days. The mean GNRI and $\mathrm{Hb}$ level of subjects were $82,29 \pm 16.39$ and $11.98 \pm 2.59 \mathrm{mg} / \mathrm{dL}$, respectively. Among 55 patients who completed this study, 10 (18.2\%) had depression and $45(81.8 \%)$ patients had no depression. In addition, nine (16.4\%) patients died and $46(83.6 \%)$ patients came back home.

The characteristics of patients based on the GNRI score is presented in TABLE 2. It was showed that the mean age subjects with GNRI score $<82 \quad(68.16 \pm 5.6$ years $)$ was not significantly different with those with GNRI score $\geq 82(67.65 \pm 6.13$ years $)(p=0.677)$. No significant difference was also observed in gender of subjects $(p=0.126)$ and in subjects with depression $(p=0.069)$ between the two groups (GNRI score $<82$ vs GNRI score $\geq 82$ ). In contrast, the $\mathrm{Hb}$ value of subjects in group with GNRI $<82$ was significantly different compared to those with GNRI $\geq 82(p=0.030)$. The group with GNRI $<82$ had higher $\mathrm{Hb}$ value $<10 \mathrm{mg} / \mathrm{dL}$ than the group with GNRI $\geq 82$. In contrast, the group with GNRI $\geq 82$ had higher $\mathrm{Hb}$ value $\geq 10 \mathrm{mg} / \mathrm{dL}$. Furthermore, the Charlson index of the group with GNRI $<82(4.6 \pm 2.7)$ was signifantly higher than those of the group with GNRI $\geq 82(2.72 \pm 1.8)(p=0.016)$. Length of stay of group with GNRI $<82(14.32$ \pm 8.2 days) was significantly higher than those of group with GNRI $\geq(9.31 \pm 6.15$ days $)(p=$ $0.006)$. Likewise, mortality rate of the group with GNRI $<82(42.1 \%)$ was higher than those of group with GNRI $\geq 82(2.8 \%)(p=0.000)$.

TABLE 1. Characteristics of subjects

\begin{tabular}{lc}
\hline Variables & $\begin{array}{c}\text { Mean } \pm \text { SD or } \\
\text { Proporsi }(\mathrm{N})\end{array}$ \\
\hline Age (year) & $67.82 \pm 5.91$ \\
Charlson index & $3.36 \pm 2.35$ \\
Length of stay (day) & $11.04 \pm 7.27$ \\
GNRI* & $82.29 \pm 16.39$ \\
Hb (mg/dL) & $11.98 \pm 2.59$ \\
Male & $65.5 \%(36)$ \\
Female & $34.5 \%(19)$ \\
Depression & $18.2 \%(10)$ \\
No Depression & $81.8 \%(45)$ \\
Death & $16.4 \%(9)$ \\
Live & $83.6 \%(46)$ \\
\hline
\end{tabular}

*GNRI: Geriatric Nutritional Risk Index 
TABLE 2. Subjects' characteristics based on GNRI value

\begin{tabular}{lccc}
\hline Variables & GNRI $<82$ & GNRI $=82$ & $\mathrm{p}$ \\
\hline Age (year) & $68.16 \pm 5.6$ & $67.65 \pm 6.13$ & 0.677 \\
Charlson index & $4.6 \pm 2.7$ & $2.72 \pm 1.8$ & $0.016^{*}$ \\
Male & $78.9 \%$ & $58.3 \%$ & \\
Female & $21.1 \%$ & $41.7 \%$ & 0.126 \\
$\mathrm{Hb}<10 \mathrm{mg} / \mathrm{dL}$ & $36.8 \%$ & $11.1 \%$ & \\
$\mathrm{Hb}=10 \mathrm{mg} / \mathrm{dL}$ & $63.2 \%$ & $88.9 \%$ & $0.030^{*}$ \\
Depresion (DSM IV-TR) & $31.6 \%$ & $11.1 \%$ & 0.069 \\
Length of stay (day) & $14.32 \pm 8.20$ & $9.31 \pm 6.15$ & $0.006 *$ \\
Mortality & $42.1 \%$ & $2.8 \%$ & $0.000^{*}$ \\
\hline
\end{tabular}

*) $p<0.05$ : significantly different

Length of stay of subjects in the hospital based on the characteristics of subjects is presented in TABLE 3. Length of stay of subjects was influenced by depression and GNRI value, however it was not influenced by gender and $\mathrm{Hb}$ value. Subjects who experienced depression $(14.40 \pm 4.20$ days) had longer length of stay than those who not experienced depression $(10.29 \pm 8.20$ days $)(p=0.003)$. In addition, subjects of group with GNRI $<82(14.32 \pm 8.20$ days) had longer length of stay than those in group with GNRI $\geq 82(9.31 \pm 6.15$ days $)(p=$ 0.006).

TABLE 3. Length of stay of geriatic patients in the hospital

\begin{tabular}{|c|c|c|}
\hline Variables & Length of Stay (day) & $\mathrm{p}$ \\
\hline $\begin{array}{l}\text { Gender } \\
\text { - Male } \\
\text { - Female }\end{array}$ & $\begin{array}{l}10.58 \pm 7.00 \\
11.89 \pm 7.87\end{array}$ & 0.311 \\
\hline $\begin{array}{l}\text { Hb value } \\
\cdot<10 \mathrm{mg} / \mathrm{dL} \\
\cdot \geq 10 \mathrm{mg} / \mathrm{dL}\end{array}$ & $\begin{array}{l}14.00 \pm 9.99 \\
10.00 \pm 6.35\end{array}$ & 0.249 \\
\hline $\begin{array}{l}\text { Depression status } \\
\text { - Depression } \\
\text { - No depression }\end{array}$ & $\begin{array}{l}14.40 \pm 4.20 \\
10.29 \pm 7.60\end{array}$ & $0.003 *$ \\
\hline GNRI score & & \\
\hline $\begin{array}{l}\cdot<82 \\
\cdot-282\end{array}$ & $\begin{array}{c}14.32 \pm 8.20 \\
9.31 \pm 6.15\end{array}$ & $0.006^{*}$ \\
\hline
\end{tabular}

The correlation between characteristics of subjects and length of stay in hospital is presented in TABLE 4. No significant correlation was observed between length of stay in hospital with age, Charlson index, gender, depression status as well as $\mathrm{Hb}$ value $(\mathrm{p}>0.05)$.
However, negative significant correlation was observed between the length of stay and GNRI score $(p=0.006 ; r=-0.352)$ as presented in TABLE 4 and FIGURE 1 . Subjects with higher GNRI score had shorter length of stay in the hospital. 
TABLE 4. Correlation between the length of stay in hospital and characteristics of geriatric patients

\begin{tabular}{lcc}
\hline Variables & $\mathrm{r}$ & $\mathrm{p}$ \\
\hline Age (year) & -0.044 & 0.750 \\
Charlson index & -0.057 & 0.681 \\
GNRI & -0.352 & $0.006^{*}$ \\
Gender & 0.021 & 0.654 \\
Depression & 0.043 & 0.150 \\
$\mathrm{Hb}<10 \mathrm{mg} / \mathrm{dL}$ & -0.157 & 0.253 \\
\hline$*) \mathrm{p}<0.05$ : significantly different &
\end{tabular}

The characteristics of geriatric patients accordint to mortality are presented in TABLE 5. The age, gender and depression status were not significantly associated with mortality in

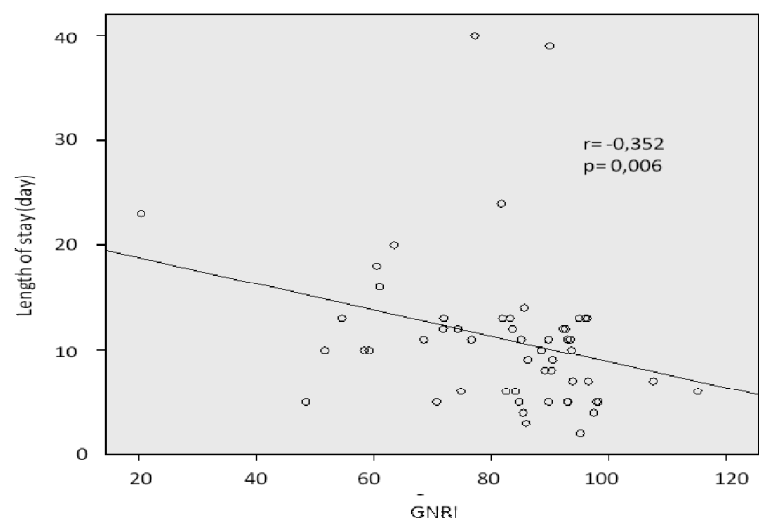

FIGURE 1. Relationship between length of stay and GNRI

geriatric patients $(\mathrm{p}>0.05)$. However, the mortality in the geriatic patients significantly associated with their Charlson index, $\mathrm{Hb}$ and GNRI values $(p<0.05)$.

TABLE 5. Factors related to mortality rate of subjects

\begin{tabular}{|c|c|c|c|c|c|}
\hline Variables & $\begin{array}{c}\text { Death } \\
\text { Proportion }(\% / \mathrm{N})\end{array}$ & $\mathrm{N}$ total & $\mathrm{RR}$ & $95 \%$ CI & $\mathrm{p}$ \\
\hline $\begin{array}{l}\text { Age } \\
\cdot \quad<70 \text { year } \\
\cdot \quad \geq 70 \text { year }\end{array}$ & $\begin{array}{l}21.1(8) \\
5.9(1)\end{array}$ & $\begin{array}{l}38 \\
17\end{array}$ & 3.58 & $0.485-26.409$ & 0.156 \\
\hline $\begin{array}{l}\text { Charlson index } \\
\begin{array}{l}->3 \\
\cdot \quad \leq 3\end{array}\end{array}$ & $\begin{array}{c}36.4(8) \\
3(1)\end{array}$ & $\begin{array}{l}22 \\
33\end{array}$ & 12.00 & $1.612-89.349$ & $0.002 *$ \\
\hline $\begin{array}{l}\text { Gender } \\
\text { - Malc } \\
\text { - Female }\end{array}$ & $\begin{array}{l}19.4(7) \\
10.5(2)\end{array}$ & $\begin{array}{l}36 \\
19\end{array}$ & 1.85 & $0.425-8.033$ & 0.330 \\
\hline $\begin{array}{l}\text { Hb value } \\
\cdot \quad<10 \mathrm{mg} / \mathrm{dL} \\
\cdot \quad>10 \mathrm{mg} / \mathrm{dL}\end{array}$ & $\begin{array}{l}36.4(4) \\
11.4(5)\end{array}$ & $\begin{array}{l}11 \\
44\end{array}$ & 3.20 & $1.027-9.973$ & $0.045^{*}$ \\
\hline $\begin{array}{l}\text { Depresion status } \\
\text { - Depression } \\
\text { - No Depression }\end{array}$ & $\begin{array}{c}30(3) \\
13.32(6)\end{array}$ & $\begin{array}{l}10 \\
45\end{array}$ & 2.25 & $0.675-7.505$ & 0.200 \\
\hline $\begin{array}{c}\text { GNRI value } \\
\cdot \quad<82 \\
\cdot \quad \geq 82\end{array}$ & $\begin{array}{l}42.1(8) \\
5.6(1)\end{array}$ & $\begin{array}{l}19 \\
36\end{array}$ & 15.18 & $2.045-112.360$ & $0.001 *$ \\
\hline
\end{tabular}

*) $p<0.05$ : significantly different

Survival rate for patients based on GNRI group can be seen on the Kaplan-Meier curves as presented in FIGURE 2. Patients with GNRI score $<82$ had rapidly decreased survival rate when compared with those with GNRI score $\geq$ 82. 




FIGURE 2. Kaplan-Meier survival analysis of patients with GNRI $<82$ and $\geq 82$.

\section{DISCUSSION}

This study showed that the length of stay of subjects was influenced by depression and GNRI value, however it was not influenced by gender and $\mathrm{Hb}$ value. Subjects who experienced depression (14.40 \pm 4.20 days) had longer length of stay than those who not experienced depression $(10.29 \pm 8.20$ days $)(p=0.003)$. In addition, subjects of group with GNRI $<82$ (14.32 \pm 8.20 days) had longer length of stay than those in group with GNRI $\geq 82(9.31 \pm$ 6.15 days $)(p=0.006)$.

Previous study conducted in Sanglah Hospital, Bali found a negative correlation between GNRI scores and the length of hospitalization. ${ }^{11}$ Moreover, a study in geriatric patients hospitalized in France also showed the relationship between the length of hospitalization and GNRI. ${ }^{12}$ However, these results is not supported with other study that reported no significant correlation between the length of hospitalization and GNRI. ${ }^{13}$

Consistent with this study, a study conducted in Queen Elisabet Geriatric Center, Victoria reported no significant difference in the length of hospitalization was observed between male and female geriatric patients. ${ }^{14}$ In contrast with this study, a significant association between $\mathrm{Hb}$ level and the length stay in patients undergoing operations was observed. ${ }^{15,16}$ This difference may be caused the difference of patients observed.

This study also showed that the mortality rate was influenced by Charlson index, $\mathrm{Hb}$ and GNRI values, however it was not influenced by age, gender and depression status. The mortality rate of patients with GNRI score $<82$ (42.1\%) was significantly higher than those with GNRI score $\geq 82(2.8 \%)(p=0.001)$. In addition, the mortality rate of patients with $\mathrm{Hb}$ value $<10 \mathrm{mg} / \mathrm{dL}(36.4 \%)$ was significantly higher than those with $\mathrm{Hb}$ value $>10 \mathrm{mg} / \mathrm{dL}$ $(11.4 \%)(p=0.045)$. The mortality rate of patients with Charlson index $<3(36.4 \%)$ was also higher than those with Charlson index $\leq 3$ $(3.0 \%)(p=0.002)$.

Consistent with this study, a prospective observational study involving 358 elderly newly admitted to a long-term care setting in Italy reported nutritional risk by GNRI, but not nutritional status by MNA, was associated with higher mortality risk. ${ }^{17}$ Other studies also showed the relationship between GNRI and mortality in hospitalized elderly patients. ${ }^{6,12}$

As found in this study, the presence of comorbidities has been known to worsen the prognosis of patients. Charlson index has been evaluated in numerous studies as a predictor of mortality in the future..$^{18,19}$

In contrast with this study, a study conducted on heart bypass surgery patients showed that patients with $\mathrm{Hb} \leq 10 \mathrm{mg} / \mathrm{dL}$ showed postoperative mortality rate in the hospital 10 times higher than those with $\mathrm{Hb}>10 \mathrm{mg} / \mathrm{dL}$. In addition, low $\mathrm{Hb}$ level, severity as well as comorbidity is a major determinant of patients survival. ${ }^{20}$ Another study conducted in anemia patients who underwent percutaneous coronary intervention showed lower post-action survival 
rate than those without anemia with a 4 -fold relative risk. ${ }^{21}$

Number of male patients who died were higher than female patients in this study, although it was not significantly different. Some studies gave different results regarding the relationship of gender with mortality rate. A study conducted in Japan showed that male patients had a greater risk for death than women. ${ }^{22}$ Another study in elderly patients who suffered from a hip fracture showed that female gender was an independent and significant risk factor for mortality. However, other studies found no differences between the sexes. ${ }^{23}$

Geriatric patient with depression had higher mortality rate than those without depression in this study, although it was not significant different. Studies in patients with cardiac symptoms showed that mortality at 2year folow-up was higher in patients with depression. ${ }^{24}$ The difference is probably due to the research subjects or the difference of duration of folow up.

\section{CONCLUSION}

In conclusion, there is negative correlation between GNRI with length of hospitalization and mortality rate in elderly who admitted to the Internal Medicine Ward in the hospital. Further study with a larger subjects and a wider range of cases should be encouraged. In addition, elderly patients with GNRI score < 82 should get improved nutrition therapy to reduce the length of stay and mortality rate.

\section{ACKNOWLEDGEMENTS}

We would like to thank Head of Department of Internal Medicine, Faculty of Medicine/Dr. Sardjito General Hospital, Universitas Gadjah Mada, Yogyakarta for his permission to conduct this study. We would also like to thank all elderly patients and their families who have participated and supported in this study.

\section{REFERENCES}

1. United Nations, Department of Economic and Social Affairs (DESA), Population Division. World Population Ageing: 1950-2050. New York: United Nations, 2009.

2. United Nations, Department of Economic and Social Affairs (DESA), Population Division. World Population Ageing 2013. New York: United Nations, 2013.

3. Law DK, Dudrik SJ, Abdou NI. Immunocompetence of patients with protein calorie malnutrition. The effect of nutritional repletion. Ann Intern Med 1973; 79(4):545-50.

4. Hajjar RR, Kamel HK, Denson K. Malnutrition in aging. Int J Geriat Gerontol 2004; 1(1): 1-5.

5. Guigoz Y. The Mini Nutritional Assessment $\left(\mathrm{MNA}^{\circledR}\right)$ review of the literature - What does it tell us? J Nutr Health Aging 2006; 10(6):466-87.

6. Bouillanne O, Morineau G, Dupont C, Coulombel I, Vincent JP, Nicolis I, et al. Geriatric Nutritional Risk Index: A new index for evaluating at-risk elderly medical patients. Am J Clin Nutr. 2005; 82(4):777-83.

7. Cereda E and Pedroli C. The use of the Geriatric Nutritional Risk Index (GNRI) as a simplied nutritional screening tool. Am J Clin Nutr 2008; 87(6):1966-7.

8. Cereda E, Pusani C, Limonta D, Vanotti A. The association of Geriatric Nutritional Risk Index and total lymphocyte count with short-term nutritiontelated complications in institutionalised elderly. J Am Coll Nutr 2008; 27(3): 406-13.

9. Expert Consultation WHO. Appropriate bodymass index for Asian populations and its implications for policy and intervention strategies. Lancet 2004; 363(9403):157-63.

10. Pugh RN, Murray-Lyon IM, Dawson JL, Pietroni MC, Williams R. Transection of the oesophagus for bleeding oesophageal varices. Br J Surg 1973; 60(8):646-9.

11. Andriyasa K, Kuswardhani T, Aryana IS, Astika N, Putrawan IB. Korelasi antara Geriatric Nutritional Index dengan lama rawat pasien geriatri di Rumah Sakit Sanglah, Denpasar. J Peny Dalam 2011; 12:115-20.

12. Bougeant PL, Berthier F, Scotti M, Joseph D, Marimoutou C, Schneider SM. An independent influence of nutrional risk on the length of hospital stay. Clin Nutr Suppl. 2008; 3: 135 
13. Gómez JJL, Casariego AV, Laranjo CB, Vicente EF, García RM, Rodríguez IC, et al. Screening of the nutritional risk in elderly hospitalized patients with different tools. Spain: León. Sección de Endocrinología y Nutrición, Complejo Asistencial Universitario de León. 2011.

14. Hubbart WA. Rehabilitation outcomes for elderly lower limb amputees. Austr J Physiother 1989; 35(4): 219-24.

15. Wang X, Rintala DH, Garber SL, Henson HK. Association of hemoglobin level, age and comorbidities with rehabilitation outcomes after total knee replacement. Am J Phys Med Rehabil 2005; 84(6):451-6.

16. Burr RG, Peace CL, Nuseibeh I. Haemoglobin and albumin as predictor of length of stay of splinal injured patients in a rehabilitation centre. Paraplegia 1993; 31(7): 473-8.

17. Cereda E, Pedrolli C, Zagami A, Vanotti A, Piffer $\mathrm{S}$, Opizzi A, et al. Nutritional screening and mortality in newly institutionalised elderly: A comparison between the Geriatric Nutritional Risk Index and the Mini Nutritional Assessment. Clin Nutr. 2011; 30(6):793-8.

18. Murray SB, Bates DW, Ngo L, Ufberg JW, Shapiro NI. Charlson index is associated with one-year mortality in emergency department patients with suspected infection. Acad Emerg Med 2006; 13(5):530-6.
19. Charlson ME, Pompei P, Ales KL, MacKenzie CR. A new method of classifying prognostic comorbidity in longitudinal studies: development and validation. J Chronic Dis 1987; 40(5):37383.

20. Zindrou D, Taylor KM, Bagger JP. Preoperative haemoglobin concentration and mortality rate after coronary artery bypass surgery. Lancet 2002 ; 359(9319):1747-8.

21. Reinecke H, Trey T, Wellmann J, Heidrich J, Fobker M, Wichter T, et al. Haemoglobin-related mortality in patients undergoing percutaneous coronary interventions. Eur Heart J 2003; 24(23):2142-50.

22. Haraguchi Y, Osaki Y, Mazume M, Kishimoto T, Yakura N, Okamoto M. Risk factors for death among the functionally independent elderly living in Japan: a 3-year prospective cohort study. Yonago Acta Med 2006; 49:93-101

23. Ozturk A, Ozkan Y, Akgöz S, Yalçýn N, Özdemir RM, Aykut S. The risk factors for mortality in elderly patients with hip fractures: postoperative one-year results. Singapore Med J 2010; 51(2):137-43.

24. Rutledge T, Reis SE, Olson M, Owens J, Kelsey $\mathrm{SF}$, Pepine CJ, et al. Depression is associated with cardiac symptoms, mortality risk, and hospitalization among women with suspected coronary disease: the NHLBI-sponsored WISE study. Psychosom Med 2006; 68(2):217-23. 